Ebhohimhen, A. Avenell / / Obesity Reviews. - 2007. - № 23. P. 1-13.

12. Wing R. B. Benefits of recurring participants with friends and increasing social support for weight loss and maintenance / R. B. Wing, R. W. Jeffery // Journal of Consulting and Clinical Psychology. - 1999. - № 67. - P. 132-138.

Received October 24, 2017 Revised November 16, 2017 Accepted December 19, 2017

\title{
A self-sufficient personality in the SPIRITUAL dimension
}

Biloshytska A. S. A self-sufficient personality in the spiritual dimension / A. S. Biloshytska // Problems of Modern Psychology : Collection of research papers of Kamianets-Podilskyi National Ivan Ohiienko University, G. S. Kostiuk Institute of Psychology of the National Academy of Educational Sciences of Ukraine / scientific editing by S. D. Maksymenko, L. A. Onufriieva. - Issue 39. - Kamianets-Podilskyi : Aksioma, 2018. - P. 31-42.

A. S. Biloshytska. A self-sufficient personality in the spiritual dimension. The article dwells upon the issues of personal self-sufficiency in the dimension of spirituality. The generalized survey of psychological, culturological, philosophic, historical and religious studies on the problematic of spirituality of a self-sufficient person is represented.

The categories of spirituality and self-sufficiency are regarded within the connection with notions of existence, wisdom, happiness, well-being, good, contemplation, morality as well. Theoretical objectivation of selfsufficiency as a psychological background for the self-development and self-becoming of a spiritually oriented person is proposed. An attempt to separate the positive and negative vectors for the elaboration of the problems of the spiritual formation of a self-sufficient person based on the concepts of the religious outlook, creative self-expression, self-development and self-realization of the sage was carried out.

The presented analysis of the literature sources concluded two main directions in describing self-sufficiency as both definitely negative and positive personality trait, contributing parameter of spirituality growth. 
The spiritual essentials of self-sufficiency such as realization of conscious activity towards actions of achieving high purposes, discovery of blessing, striving to well-being, sense of spiritual and immaterial happiness, interest to creativity despite all outer obstacles makes a way to selffulfillment are marked out. Ingenious soul freedom, absence of prejudices and openness to the social and cultural changes as determinants of a spiritually oriented and mature self-sufficient person were revealed.

Self-sufficiency as an individual psychological particularity is considered to be the significant spiritual trait being a ground for manifestation of self-consciousness, perception of personal potential and desires.

Key words: self-sufficiency, a self-sufficient person, spirituality, transformations, experience of self-sufficiency, contemplation.

А. С. Білошицька. Самодостатня особистість у духовному вимірі. Статтю присвячено питанням особистісної самодостатності у вимірі духовності. Представлено узагальнене дослідження психологічної, культурологічної, філософської, історико-релігієзнавчої проблематики духовності самодостатньої людини.

Категорії духовності та самодостатності розглядаються у зв’язку з поняттями екзистенції, мудрості, щастя, благополуччя, добра, споглядання, моралі. Запропоновано теоретичне обгрунтування самодостатності як психологічного підгрунтя для саморозвитку та становлення духовно орієнтованої людини. Здійснено спробу виокремлення позитивних і негативних векторів розробки проблем духовного формування самодостатньої людини на основі концептів релігійного світогляду, творчого самовираження, саморозвитку та самореалізації мудреця.

Представлений аналіз літературних джерел висвітлив два основних напрями в описі самодостатності як суто негативної, так і позитивної риси особистості, що сприяє зростанню духовності.

Визначено, що духовними сутнісними складовими самодостатності є реалізація свідомої діяльності у напрямку досягнення високих цілей, відкриття благословення, прагнення до благополуччя, відчуття духовного і нематеріального щастя, інтерес до творчості, незважаючи на усі зовнішні перешкоди. Виявлено, що вроджена свобода душі, відсутність упереджень та відкритість до соціальних і культурних змін творять духовно орієнтовану та зрілу самодостатню людину.

Самодостатність як індивідуальна психологічна особливість вважається істотною духовною ознакою, що є основою для прояву самосвідомості, прийняття особистого потенціалу та бажань.

Ключові слова: самодостатність, самодостатня особистість, духовність, трансформації, досвід самодостатності, споглядання.

Statement of the problem. In the context of ontic changing conditions in society, cultural and economic transformations, a person becomes a target for the events, which can be truly considered as 
psychological and spiritual challenges, too difficult for overcoming. The external alterations affect the internal way of life and worldview of a personality frequently in the unwholesome way, which lead to a deterioration in mental, physical and social health. Taking into the account current upheavals, that cause negative assessment from the side of society members, as well as resistance or active struggle, the problem of preserving psychological and spiritual well-being must not be ignored. For this reason, importance is being increasingly attached to the issue of spirituality of a self-sufficient personality.

As the given psychological concern is frequently compared with other individual features, belonging to the description of inwardness (notion in the meaning that relates more to the inner strength and potential, rather than to spirituality and spiritual essence), the questions to discuss are set. To be exact - what makes a self-sufficient personality spiritually oriented and creates the conditions for spirituality growth. Thus, the given paper is dedicated to the selfsufficiency issue in the context of spirituality.

Analysis of the recent studies. Without setting the question of profound analysis of the recent studies on the subject of personal self-sufficiency the short survey of the works is presented. A generalized inquiry of the approaches to self-sufficiency investigation can be divided into the directions, considering the phenomenon:

1) as a protective mechanism (common for a narcissistic person (R. Raskin, A. Modell, D. K. Lapsley), motive of independency of an abused individual (R. Klein, H. Guntrip), introvert (C. Jung), neurotic (K. Horney), in the context of behavior dealing with finances (K. D. Vohs, N. L. Mead, M. R. Goode);

2) as a social-psychological adaptation marker (through representation of someone's inner world (F. Perls), social activity (A. Adler), functional autonomy (G. Allport), in pedagogical support and accomplishment (O. V. Hrechanik, O. V. Melnik, L. V. Volkova, etc.), assertiveness - independence - achievement strivings shame - guilt (Y.-H. Chao, Y.-Y. Cheng, W. -B. Chiou);

3) as an integral psychological personality trait (going out of self-confidence, self-efficacy, authenticity, holism, well-being (N. Labuschagne, P. Cavallero, M. G. Ferrari, B. Bertocci, M. Bingham, A. Bandura, etc.).

The extensive analysis of the literature, presented by M. G. Murashkin, who regards self-sufficiency as a source of personal mysti- 
cal experiences [7], in fact, is all but the exclusive focus of approaches to the study of self-sufficiency, including its spiritual side. Relying on the numerous works of mystics, philosophers, psychologists, etc., the author reveals the depth of this concept in ancient times and the postmodern era. Accordingly, there are two opposite vectors of the study of self-sufficiency in the context of the spirituality of the individual. The first course implicates the positive influence of this characteristic on the spiritual growth of the personality. The second approach to the phenomenon reflects self-sufficiency as a mystical idea, a prerequisite for spiritual formation (mystical ecstasy, experience, insight, illumination, enlightenment, delight, inspiration, creative impulse).

Unfortunately, there is no distinct understanding who we can call a self-sufficient spiritual person or spiritually oriented with reference to the abundant literature sources. The reason is the fact that there is no singular definition of self-sufficiency, as phenomenon is discussed in several scientific and non-scientific scopes. In addition, in the dimension of spirituality given term is described through the concepts, denoting particular state of consciousness or personal trait of a wise man.

Nevertheless, it is evident that none of the authors has considered spirituality of a self-sufficient person. Therefore, the purpose of our article is to clarify the role of self-sufficiency in the spiritual dimension of human life. Correspondingly, the tasks of the investigation comprise the review of historical, cultural, ethical, psychological and philosophical resources on self-sufficiency as a spirituality basis for a man to get over the severities of life.

Main material. In the current era of contemporary dynamic conversions in social and cultural environment, each member of any community is required to respond particular needs in priority. These needs relate both to accepting alternations from outer world and adoption, and as a result - embodiment of cutting edge technologies and brand new solutions of functioning in the society and personal everyday living.

Consequently, an urgent problem to solve is obvious: how to protect a person, making his peace of mind resistant to the negative consequences of the happening events. In this regard, there is a great need to analyze the issue that is relevant to our time - spirituality sphere of a self-sufficient person and its contribution to betterment of life. 
Based on the social and cultural issues of nowadays presented before, the primary task is to determine the reference point in the understanding of human spirituality. The precise idea what is spirituality the essence is suggested by $\mathrm{D}$. A. Leontiev, who explains that is the highest level of development and self-regulation of a mature personality, whose vital activity is matched with higher human values in hierarchical interrelations (motivational and semantic regulators) [6].

Spirituality, which for centuries was the subject of studying of philosophy and theology, now becomes an object of close attention from the psychological science. It is important to admit, that modern psychology, which is based on materialistic philosophical outlooks, has no straight relation to spiritual life. The appeal of psychology to spirituality as a real subject of studying will open the perspectives of the investigation of inner world of a man, which enables broadening of mind and thus - development of different scientific approaches to the studying a personality.

Herewith L. Z. Levit, the author of the work «Spirituality as the research, discovery and realization of the inner ideal», considers spiritual strivings of an individual as a potential for realization of personally oriented concept of happiness. It means that by personal spirituality one can have a temporary shelter (from meaningless pleasures of contemporary times) to balance appearance of disproportions [4, p. 103-104].

Therefore, self-sufficiency refers to a negative value, when it is described through the prism of spiritual and moral quality, manifested in the confidence of the individual in the fullness of his capabilities and the ability to provide the solution of the problem autonomously. It is categorically assessed the very behavior of a selfsufficient person: he considers himself assertive and self-assured in his activities, ready to deal with any issues, stubborn. At the same time, it is noteworthy to underline a quite different meaning of the concept in the spiritual dimension - availability of internal resources that allows developing independently from external factors. Nevertheless, the conclusion on this position is unambiguous: self-sufficiency is a sign of a weak spiritual development of man, a reliance only on one's own strength [1]. In fact, this idea touches upon the basis of Christian dogmatic theology, according to which, one of the properties of God is His self-sufficiency [9].

The religious philosopher and writer B. Levit-Broun, belittles the role of self-sufficiency, convincing that it is hostile to man and 
is the misfortune of the soul: «... Anyone who internally exists (... does not vegetate!), is in the process of spiritual becoming-existence, knows that there is no self-sufficiency, that the personality is fully valuable only in conjunction with another personality, and in the spiritual limit in unity with all individuals - in a conciliar spirit. Another thing is that a person must necessarily have within himself a self-supporting spiritual core, and not twist like ivy around some external support for her. Nevertheless, the person cannot be finally sufficient for himself. A way out is needed, as well as communication, bringing created inner content into recognition, in possession of other personalities. So the person feels aware of himself until the end...» $[5$, p. 59].

The researcher treats self-sufficiency in a negative way, explaining that every hint of creativity, hidden from our eyes, given by God, is neglected, if a person states his self-sufficiency. It is destruction of inner harmony and balance between a man and world outside.

To illustrate the fatality of chosen self-sufficiency way to tread through all person's life, the writer gives the comparing of perception of given notion in the planes of Christian and Buddhist religions. "There are many philosophical and religious-philosophical attempts to form, create, construct self-sufficiency of an individual. All of them were, and still are, efforts to protect themselves from the suffering of non-separateness, from the hurting encounters with an alien and uneventful world... The Christian spirit cannot accept the idea of self-sufficiency either in the form of Buddhist nirvana or in the form of stoic autarky-apathy, for both are based on recognition the invincibility of world evil and the futility of human destiny in the world. Self-sufficiency takes away human life, extinguishes the creative spirit given to man by God, kills freedom, and fixes the beginning in the chains of necessity. To recognize selfsufficiency as the spiritual norm means to abandon the hope for the survival of humanity, for humanity is a meeting, this is a union in an impending spiritual disclosure... But creativity in a person is invincible and indestructible hope for spiritual unfoldment in an existential meeting of mutual understanding. Therefore, self-sufficiency will always be hostile to the human spirit; it will always be a misfortune for the soul» [5, p. 59-60].

The famous apologist of the middle ages, Augustine of Hippo, appealed to a man with a request to become stronger than his weak- 
ness and strive for an unchanging truth. Therefore, self-sufficiency in his understanding is a consequence of the confrontation of human variability and the constant desire to know oneself and the truth [10].

The concepts of the philosopher-theologian S. V. Solovyov towards the issue of a self-sufficient personality are connected with the principle of self-sufficiency in the life comparing with the good, freedom, independence and happiness of a man. Considering eudemonism as a self-sufficient essence [11, p. 57], the thinker emphasizes the idea that self-sufficiency is nothing but a desire for wellbeing, leading to a moral deliverance from all attachments, and this means the primacy of the spirit over the flesh.

Another famous philosopher N. Berdiaev defines a self-sufficient person as an individualist (who takes personal course of actions and follows self-generated strategy): one can be independent, authentic, does not mix with the crowd, or conversely - hating people, egocentric, not capable to communicate with society, - and that depicts an individualist too. On the other hand, inwardness, which guides self-sufficiency, supports unity of spiritual life and creates the personality [16, p. 115]. Moreover, thuswise any fears are conquered by integrative, centralized personality who possesses sense of self-worth and straightly resists forces from outside.

Undoubtedly, the spiritual world of a person is reflected in the motives, values, principles, beliefs, faith, knowledge, moral, spiritual, and aesthetic feelings, and its self is expressed in the forms of self-awareness - self-sufficiency, vocation, self-actualization, self-actualization. Accordingly, the spiritual principle is the core of the moral life and creative power of the individual. All this leads to the conclusion that the sense of personality is found in the world of values and living social experience, in turning to God [2]. The researcher V. V. Kizima touches upon the problematic of self-sufficiency in the context of self-organized, self-contained integrity, which is regarded in two conceptual layers - actual and potential. The first underlines the characteristic of external act of behaviour. The second one is about regulative-spiritual potencies, centre of self-awareness, centre of will and character core.

V. Zenkovsky pointed out that self-sufficiency cannot be separated from the aspect of spirituality and is inextricably linked with the spiritual life vector. In order to avoid a deep immersion in the very behavior and escape from self, the only true means is to open 
the spiritual world, leveling or avoiding impressions that destructively affect the soul from the outside, as well as loneliness, taciturnity, etc. [3, p. 47-48].

As we can see the philosophers and scientists of New Era showed somewhat deep and philosophical attitude to the questions of selfsufficiency and spirituality. It is interesting to underline that displayed opinions are produced by social and cultural alternations, which occur in everyday life, and we can be the witnesses of happening transformations nowadays. Also there is another layer of philosophical perception of antic self-sufficiency and spirituality issues, which originated from ancient times and is the significant viewpoint for the researcher of sciences in contemporary conditions. The matter is, Hellenistic sophist were the first to discover the interrelation between the categories of self-sufficiency and morality. Going back to old times to reveal the spiritual essentials, it is noteworthy to add that all the ideas, which had the roots from ancient times, developed and were elaborated by different experts, not only in the aspect of philosophy, psychology or religion studies.

It is worth mentioning that in the glory days of the Stoic thought, the ethical ideal was impartiality, and in order to gain this inner calm, it was necessary to learn to control someone's self, knowing and controlling the actions. Concurrently, the sophistic school of Cynics introduced a system of four steps in the path of self-development. One of these steps provided, that the sage finds spiritual freedom, regardless of the distortion of external life forms, positive and negative values of the life process (aytarceia) [7]. It is obvious that, following this path of self-development, the sage acquires complete independence from the outside world, towering over all its forms and affirming his own spiritual freedom and self-sufficiency.

In the works of Aristotle a specific separation between the autarky-principle and the autarky-state of a man was concluded. In the first case the subject is self-sufficiency, self-support, and in the second case, the spectrum of characteristics is «blissful», "grand», "wise» [7, p. 202]. He points out that the majority of people is very rude (phortikotatoi), understands for the good happiness of pleasure; and therefore for them the desired life is full of pleasures. After all, there are three basic lifestyles: first, just mentioned, secondly, sovereign or powerful and, thirdly, contemplative. People worthy and active (praktikoi) understand under the blessing and happiness respect. However, this thing is not as bright as the blessing in 
search, which proposes third lifestyle - thoughtful, introspective, considerate.

Aristotle explains that everything that a person does consciously (and this can be attributed to the chosen lifestyle) is dictated by the purpose, and it is the highest blessing. The perfect goal can be called happiness, because people choose it for its own sake, and not for the sake of realizing through it another desire, goals. The philosopher offers the approaches to the definition of self-sufficiency, noting that self-sufficiency is a term, used not only in relation to a person, who leads a solitary life, but also to a person with his family, relatives, and fellow citizens. The reason is that a person is essentially a social entity.

A conscious activity with the realization of specific goals cannot be reduced to the self-sufficiency of the individual or his actions, which form the basis of integrity, deduce the individual into the society, and therefore must be self-sufficient not only to the one who performs them, but also to those, whom it may concern. Each act cannot be equated with another, self-sufficiency must be certified, but this cannot be done without general definitions.

From here, the idea of self-sufficiency and the connection of self-sufficiency, happiness and supreme good is specified - the infinity of goals and means, as well as the need to complete them with some self-sufficient purpose, the focus on higher good is essentially linked to the specifics of a person, his special place in the world.

In the period of distinct honor of the Stoics impartiality was an ethical ideal. To achieve internal peace and impartiality meant to learn to control completely one's self, to define actions only by the reasons. The nature for the stoic is rock, fate and destiny. $\mathrm{Ne}$ vertheless, to reconcile with the fate and not to resist - this is the achievement of integrity, unity with self, and hence - a real selfsufficiency.

Synthesis of sources of sophistic sensualism and relativism has shown that the philosophical and aesthetic system of cynicism was based on four basic logical steps to self-perfection.

The first step involved the dominance of sensuality, the material variability of the whole process of life over reason and pure spiritual activity. At this stage «... all animal instincts and needs were not restrained exactly by nothing, so before that, all of the achievements of civilization were scattered in the dust and the animal of the downshifting was proclaimed» [8, p. 132]. 
The second step was the formalization and schematization of the mind and its transformation into an abstract principle only.

The third - marked the nonsense of the life, that is, the whole of the basic life process is rejected, denied and declared foolish. Nothing in life is long lasting, nor anything in life can be expected, nothing in life can become a principle of conduct.

The fourth step assumed that the wise man's mind was spiritual freedom in the face of any ugliness, mutilation and in general any negative and positive values of the life process; this is self-protection (aytarceia) of the wise man. Therefore, it turns out that the wise man received from the life process a sense of complete independence from him, contempt for all his forms and the establishment of his own spiritual freedom and self-sufficiency [8, p. 185].

Hence, self-sufficiency was treated as an integral feature for the achieving of spiritual goals and open mind for a sage.

Conclusions. Summarizing the all abovementioned, we emphasize that the aspect of spirituality of a self-sufficient person is considered in the context of the significance and probable positive or negative influence of self-sufficiency on the development of the individual. The carried out analysis of theoretical elaborations makes possible to conclude, that despite the negative assessment of self-sufficiency as an individual characteristic in general, it is an essential individual psychological phenomenon, which discloses the ways, leading to the spiritual becoming of a person. A self-sufficient person percepts the world in the context of the elevation of personality over the material and strives for the protection of self from the destructive manifestations of the external world, that violates the internal harmony and betterment of human life.

The perspectives of further investigation. The further course of elaborations towards the category of self-sufficiency in the spiritual dimension can be traced towards the spiritual essentials of selfsufficient person, namely interest to creativity despite all outer obstacles, which make a man stop his way to self-fulfillment, openness to the world, social contacts, striving for immaterial well-being. The theoretical and methodological justification of the spirituality model of personal self-sufficiency will broaden the horizon for the studying of the given questions and explain the particularities of interrelations of self-sufficiency spiritual essentials. 


\section{References}

1. Безрукова В. С. Основы духовной культуры (энциклопедический словарь педагога) / В. С. Безрукова. - Екатеринбург, 2000. - 937 c.

2. Васянович Г. П. Ноологія особистості : навч. посіб. для студентів і викладачів / Г. П. Васянович, В. Д. Онищенко. Львів : Сполом, 2007. - 312 с.

3. Зеньковский В. В. Проблемы воспитания в свете христианской антропологии (Париж, 1991) / В. В. Зеньковский. - М. : Изд-во Свято-Владимирского Братства, 1993. - 224 с.

4. Левит Л. 3. Духовность как поиск, обнаружение и реализация внутреннего идеала / Л. З. Левит // Акмеология (научно-практический журнал). - 2015. - № 3 (юбилейный выпуск). - С. 103-104.

5. Левит-Броун Б. На Бога надейся: о трудностях веры и легкости безверия, о смысле, духе и человеке / Б. Левит-Броун. СПб : Изд. «Алетейя», 1998. - 355 с.

6. Леонтьев Д. А. Духовность / Д. А. Леонтьев // Касавин И. Т. Энциклопедия эпистемологии и философии науки. - Москва : «Канон+»РООИ «Реабилитация», 2009. - С. 217-218.

7. Мурашкин М. Г. Феномен самодостаточности / М. Г. Мурашкин. - Днепр. : Днепропетр. гос. фин. акад., 2005. - 300 с.

8. Нахов И. М. Философия киников / И. М. Нахов. - М. : Наука, 1982. - 224 с.

9. Николай Сербский (Велимирович), епископ. Семь ключей к вечной жизни. Мысли о пути человека к Небу. - М. : Никея, 2013. - $193 \mathrm{c}$.

10. Реале Дж. Западная философия от истоков до наших дней. От романтизма до наших дней / Дж. Реале, Д. Антисери. С.-Петербург : «Пневма», 2003. - 880 с.

11. Соловьев В. С. Сочинения : В 2 т. / В. С. Соловьев ; [сост., общ. ред. А. В. Гулыги, А. Ф. Лосева]. - М. : Мысль, 1990. T. $2-824$ c.

\section{References}

1. Bezrukova V.S. Osnovy duhovnoj kul'tury (jenciklopedicheskij slovar' pedagoga) / V. S. Bezrukova. - Ekaterinburg, 2000. $937 \mathrm{~s}$.

2. Vasjanovych G. P. Noologija osobystosti : navch. posib. dlja studentiv i vykladachiv / G. P. Vasjanovych, V. D. Onyshhenko. L'viv : Spolom, 2007. - $312 \mathrm{~s}$. 
3. Zen'kovskij V. V. Problemy vospitanija v svete hristianskoj antropologii (Parizh, 1991) / V. V. Zen'kovskij. - M. : Izd-vo Svjato-Vladimirskogo Bratstva, 1993. - 224 s.

4. Levit L. Z. Duhovnost' kak poisk, obnaruzhenie i realizacija vnutrennego ideala / L. Z. Levit // Akmeologija (nauchnoprakticheskij zhurnal). - 2015. - № 3 (jubilejnyj vypusk). S. 103-104.

5. Levit-Broun B. Na Boga nadejsja: o trudnostjah very i legkosti bezverija, o smysle, duhe i cheloveke / B. Levit-Broun. - $\mathrm{SPb}$ : Izd. "Aletejja», 1998. - $355 \mathrm{~s}$.

6. Leont'ev D. A. Duhovnost' / D. A. Leont'ev // Kasavin I. T. Jenciklopedija jepistemologii i filosofii nauki. - Moskva : «Kanon+» ROOI «Reabilitacija», 2009. - S. 217-218.

7. Murashkin M. G. Fenomen samodostatochnosti / M. G. Murashkin. - Dnepr. : Dnepropetr. gos. fin. akad., 2005. - $300 \mathrm{~s}$.

8. Nahov I. M. Filosofija kinikov / I. M. Nahov. - M. : Nauka, 1982. $-224 \mathrm{~s}$.

9. Nikolaj Serbskij (Velimirovich), episkop. Sem'kljuchej k vechnoj zhizni. Mysli o puti cheloveka k Nebu. - M. : Nikeja, 2013. $193 \mathrm{~s}$.

10. Reale Dzh. Zapadnaja filosofija ot istokov do nashih dnej. Ot romantizma do nashih dnej / Dzh. Reale, D. Antiseri. - S.-Peterburg : «Pnevma», 2003. - 880 c.

11. Solov'ev V. S. Sochinenija : V 2 t. / V. S. Solov'ev ; [sost., obshh. red. A. V. Gulygi, A. F. Loseva]. - M. : Mysl', 1990. T. $2-824 \mathrm{~s}$.

Received October 12, 2017

Revised November 9, 2017

Accepted December 14, 2017 